\title{
Strategi Pembelajaran Online Mata Melajaran PJOK di SMK pada Masa Pandemi Covid-19
}

\author{
Khun Wang Jaya, Febrita Paulina Heynoek *, Gema Fitriady \\ Universitas Negeri Malang, Jl. Semarang No. 5 Malang, Jawa Timur, Indonesia \\ *Penulis korespondensi, Surel: febrita.paulina.fik@um.ac.id
}

Paper received: 5-1-2022; revised: 22-1-2022; accepted: 29-1-2022

\begin{abstract}
This study aims to find out how the online learning strategies used by physical education teachers in sports and health at State Vocational Schools in Malang City. Using a qualitative descriptive approach with a survey research design. The variable in this research is online learning strategy. Using a sampling technique by purposive sampling, a total of 11 physical education teachers, sports and health at State Vocational Schools in Malang City. Data collection techniques in the form of interviews with interview guidelines as a research instrument. The data obtained were analyzed through 3 stages, namely data reduction, data presentation, and drawing conclusions. The results of this study indicate that the teacher's strategies used during learning, the majority use asynchronous compared to synchronous. The strategy used has several obstacles when asynchronous, namely some students do not participate in the work of the task while the constraints on synchronous learning students tend not to pay attention to the material explained. Although there are some obstacles, the teacher tries to keep the class conducive by making certain rules and joint commitments with the students, so that the class can be more conducive.
\end{abstract}

Keywords: learning strategy online, covid-19 pandemic, sport physical education and health

\begin{abstract}
Abstrak
Penelitian bertujuan untuk mengetahui bagaimana strategi pembelajaran online yang digunakan oleh guru PJOK SMK Negeri di Kota Malang. Menggunakan pendekatan deskriptif kualitatif dengan desain penelitian survei. Variabel dalam penelitian ini adalah strategi pembelajaran online. Menggunakan teknik pengambilan sampel dengan cara purposive sampling, sejumlah 11 orang guru PJOK SMK Negeri di Kota Malang. Teknik pengumpulan data berupa wawancara dengan pedoman wawancara sebagai instrument penelitian. Data yang diperoleh di analisis malalui 3 tahapan yaitu reduksi data, penyajian data, dan penarikan kesimpulan. Hasil penelitian ini menunjukkan strategi guru yang digunakan pada saat pembelajaran, mayoritas memakai asinkronus dibandingkan sinkronus. Strategi yang digunakan memiliki beberapa kendala pada saat asinkronus yaitu beberapa siswa tidak ikut serta dalam pengerjaan tugas sedangkan kendala pada pembelajaran sinkronus siswa cenderung tidak memperhatikan materi yang dijelaskan. Meskipun terdapat beberapa kendala, guru berupaya agar menjaga kelas tetap kondusif dengan membuat peraturan tertentu dan komitmen bersama dengan siswa, sehingga kelas bisa lebih kondusif.
\end{abstract}

Kata kunci: strategi pembelajaran online, pandemi covid-19, pjok

\section{Pendahuluan}

Virus Corona secara umum diketahui sebagai penyakit yang awalnya ditemukan di kota Wuhan, China pada bulan Desember 2019 dan mulai mewabah ke-Indonesia pada tanggal 2 Maret 2020. Covid-19 ini merupakan penyakit menular, dengan kata lain penyakit ini dapat menyebar, penyebarannya pun dapat secara langsung dan tidak secara langsung. Coronavirus berkorelasi dengan jenis virus yang dapat memicu penyakit seperti flu sampai penyakit yang parah seperti Middle East Respiratory Syndrome (MERS-CoV) dan Severe Acute Respiratory Syndrome (SARS-CoV) dimana virus ini merupakan varian baru yang belum pernah diketahui oleh manusia (Organization, 2020). Adapun upaya yang ditempuh dalam melawan pandemi 
Covid-19 yaitu dengan melakukan pembatasan kegiatan ataupun interaksi di masyarakat, yang saat ini dikenal dengan sebutan Physical Distancing. Dengan adanya kebijakan Pembatasan Sosial Berskala Besar (PSBB) menimbulkan beberapa hambatan dalam kehidupan masyarakat, contohnya dalam bidang ekonomi, bidang sosial dan bahkan bidang pendidikan pun terkena dampak dari kebijakan tersebut. Sehingga Menteri Pendidikan dan Kebudayaan Republik Indonesia mengeluarkan Surat Edaran Nomor 4 tahun 2020 (KEBUDAYAAN \& INDONESIA, 2020) yang menyatakan tentang pelaksanaan kebijakan pendidikan di masa darurat penyebaran Covid-19, Yaitu rangkaian aktivitas belajar mengajar dilakukan di rumah masingmasing dengan menggunakan pembelajaran secara jarak jauh/daring dengan tujuan untuk mencegah penyebaran rantai Covid-19.

Pembelajaran melalui media daring di masa Covid-19 merupakan kebijakan yang dicanangkan oleh Menteri Pendidikan dan Kebudayaan Republik Indonesia. Dengan harapan peserta didik tetap menerima pendidikan meskipun dengan keterbatasan yang dihadapi di masa pandemi Covid-19, sehingga aktivitas belajar mengajar tetap berjalan. Menurut (Sani, 2013) Pembelajaran daring dimaknai sebagai salah satu inovasi dan adaptasi dalam pendidikan dimana pembelajaran kreatif dan inovatif dilakukan oleh guru dalam upaya menciptakan peserta didik yang kreatif. Tujuan dilakukannya pembelajaran daring yaitu untuk memperkecil peluang terjadinya kontak langsung antara para peserta didik dengan guru yang dimana sistem pembelajaran secara face to face yang dapat mempercepat atau memperluas penyebaran virus Covid-19. Sehingga peserta didik diharapkan tetap mendapatkan pendidikan meskipun dengan keterbatasan yang dihadapi akibat Covid-19. hal ini menyebabkan guru harus memiliki cara supaya rangkaian aktivitas belajar mampu berjalan secara stabil. Salah satu pelajaran yang terkena dampak dari kebijakan tersebut adalah pelajaran pendidikan jasmani, kesehatan dan olahraga (PJOK).

Dengan adanya pembelajaran daring yang diterapkan, pelajaran PJOK juga terkena dampak yang awalnya menggunakan konsep tatap muka langsung, beralih pada pembelajaran daring. Adapun kendala yang dihadapi pada saat proses pembelajaran PJOK pada masa pandemi diantaranya kurang adanya pengawasan terhadap siswa sehingga ditakutkan terjadi hal yang tidak diinginkan. Dikarenakan PJOK ialah salah satu kegiatan pembelajaran yang dimana kegiatannya dilakukan lebih banyak melakukan aktivitas fisik dibandingkan teori. Hal ini sejalan dengan pendapat (Sumbodo, 2016) bahwa PJOK merupakan proses pendidikan dimana seseorang dapat meningkatkan kebugaran jasmani, keterampilan gerak, sportifitas, serta menumbuhkan pola hidup yang dipandang ideal di sepanjang hidupnya yang dimana kegiatan pembelajarannya lebih banyak aktivitas fisik/praktek dibandingkan teori. Kehadiran pandemi Covid-19, membuat pelaksanaan pembelajaran PJOK menjadi berubah yang dimana tidak semua strategi pembelajaran dapat diterapkan pada pembelajaran daring di masa pandemi covid-19. Sehingga guru dituntut untuk mampu mengatur strategi pembelajaran yang sesuai dengan keadaan pada masa pandemi saat ini.

Dalam menerapkan strategi pembelajaran pada masa pandemi covid, guru harus memiliki beberapa cara dalam menyampaikan materi pelajaran PJOK, yang berfungsi untuk membuat kegiatan pembelajaran dengan mengedepankan prinsip efektifitas dan efisiensi untuk mewujudkan tujuan yang dicapai. Dimana guru membuat paduan antara kegiatan, metode, media pembelajaran serta waktu yang dipakai guru dan siswa dalam proses kegiatan pembelajaran(Nasution, 2017). Adapun unsur-unsur yang harus ditetapkan oleh guru dalam kegiatan pembelajaran yaitu: (1) metode untuk menyampaikan bahan pembelajaran; (2) 
teknik untuk melaksanakan metode dengan sarana penunjang pembelajaran; (3) merancang penilaian; (4) merancang remedial dan; (5) merancang pengayaan (Asrori, 2013). Maka dalam penerapan strategi pembelajaran guru diharuskan memahami fungsi dan unsur-unsur dalam strategi pembelajaran agar terciptanya pembelajaran yang efektif dan efisien. Hal tersebut sependapat dengan pernyataan Ulum \& Or bahwa metode ialah cabang dari strategi yang dimana guru mengorganisasi isi pembelajaran, strategi yang baik dalam penyampaian materi pembelajaran, dan strategi dalam mengelola pembelajaran (Ulum \& Or, 2020). Sehingga pada era pandemi di Indonesia saat ini guru di wajiban menciptakan inovasi baru dalam merancang strategi pembelajaran yang relevan terhadap kondisi siswa pada saat pandemi, yang dimana pembelajaran PJOK menggunakan pembelajaran secara online atau sistem daring. Dengan demikian proses belajar mengajar yang seharusnya diimplementasikan secara tatap muka, berubah total menjadi pembelajaran secara jarak jauh dikeranakan adanya pandemi Covid-19.

Adapun artikel hasil penelitian terdahulu mengenai strategi pembelajaran seperti penelitian yang dilakukan oleh Ketaren \& Kanca menyatakan bahwa pembelajaran secara tatap muka lebih efektif, karena memungkinkan guru dalam memberikan materi secara langsung kepada siswa dan guru dapat mengevaluasi gerakan praktek secara langsung (Ketaren \& Kanca, 2021). Sedangkan hasil penelitian Jayul \& Irwanto menyebutkan bahwa metode Portal Schoology dan Vlog yang mengadopsi media video dapat digunakan untuk mendemonstrasikan gerakan-gerakan bersifat praktikum (Jayul \& Irwanto, 2020). Sedangkan dalam penelitian Yuangga \& Sunarsi mengatakan jika tata kelola strategi yang efektif dan menyenangkan dapat membuat siswa dapat lebih memahami esensi pembelajaran, seperti memanfaatkan interaksi antara siswa dan guru serta, merencanakan beberapa kuis online (Yuangga \& Sunarsi, 2020). Akan tetapi artikel terdahulu hanya berpusat pada strategi pembelajaran daring yang dimana dilakukan dengan menggabungkan pembelajaran luring dan Blended Learning serta hanya memberikan saran strategi pembelajaran yang akan digunakan pada saat pembelajaran daring. Karena adanya pandemi Covid-19 yang terjadi di Indonesia ini sangat mempengaruhi proses pembelajaran khususnya pada mata pelajaran PJOK. Sehingga terdapat perbedaan strategi yang digunakan guru pada saat kombinasi pembelajaran daring,luring dan Blended Learning dengan pembelajaran yang full daring. Hal ini menyebabkan tidak semua strategi pembelajaran dapat digunakan dalam pembelajaran PJOK secara full daring. Maka guru harus menciptakan strategi pembelajaran yang efektif, agar proses belajar mengajar dapat terlaksana dengan baik, sesuai dengan keadaan siswa di masa pandemi COVID-19.

Penelitian ini memiliki tujuan untuk mengetahui bagaimana strategi pembelajaran online yang digunakan oleh guru PJOK SMK Negeri di Kota Malang di situasi pandemi Covid-19, sehingga hasil penelitian mampu dijadikan acuan dalam menerapkan strategi pembelajaran online dan acuan bagi penelitian selanjutnya di situasi saat ini atau situasi sejenis.

\section{Metode}

Penelitian ini menggunakan jenis penelitian deskriptif kualitatif dengan desain penelitian survei. Variabel dalam penelitian yakni strategi pembelajaran online pada mata pelajaran PJOK di masa pandemic covid-19. Sampel penelitian ini sejumlah 11 orang guru PJOK SMK Negeri di Kota Malang yang diambil melalui teknik purposive sample. Instrumen penelitian ini menggunakan pedoman wawancara dan teknik pengumpulan data menggunakan wawancara semi terstruktur dengan melakukan wawancara secara tatap muka dan online menggunakan aplikasi WhatsApp. Sedangkan teknik analisis data yang digunakan mencakup 3 tahapan yaitu reduksi data, penyajian data berupa deskripsi mengenai analisis strategi 
pembelajaran online yang digunakan terutama pada mata pelajaran PJOK, dan langkah terakhir melakukan penarikan kesimpulan (Sugiyono, 2017).

\section{Hasil dan Pembahasan}

\subsection{Hasil}

Berdasarkan hasil wawancara yang dilakukan kepada guru PJOK, maka hasil penelitian dapat dideskripsikan sebagai berikut:

Tabel 1. Data Hasil Wawancara Guru PJOK SMK Negeri Di Kota Malang

\begin{tabular}{|c|c|}
\hline Pernyataan & Hasil \\
\hline $\begin{array}{l}\text { Metode } \\
\text { pembelajaran PJOK } \\
\text { pada masa } \\
\text { pandemic }\end{array}$ & $\begin{array}{l}\text { Guru PJOK di Kota Malang melakukan pembelajaran dilakukan secara } \\
\text { online/daring. }\end{array}$ \\
\hline $\begin{array}{l}\text { Strategi } \\
\text { pembelajaran yang } \\
\text { digunakan pada } \\
\text { masa pandemic }\end{array}$ & $\begin{array}{l}\text { Strategi yang digunakan guru PJOK SMK Negeri Kota Malang } \\
\text { menggunakan pembelajaran sinkronus dan asinkronus. Mayoritas guru } \\
\text { memakai pola pembelajaran dengan pendekatan langsung (metode } \\
\text { ceramah) pada saat sinkronus seperti penyampaian materi terlebih } \\
\text { dahulu menggunakan platform google meet/ zoom/ whatsapp. } \\
\text { Sedangkan pada pembelajaran asinkronus guru memberikan soft file } \\
\text { agar dapat dipelajari berulang-ulang, namun ada juga guru yang } \\
\text { menawarkan peluang kepada siswa untuk mencari materi pembelajaran } \\
\text { di internet sesuai dengan tema yang dipelajari. Setelah itu, guru akan } \\
\text { membebankan tugas kepada siswa untuk merangkum/menganalisis } \\
\text { materi yang telah dikaji. Pada saat pembelajaran praktik guru } \\
\text { menggunakan metode demonstrasi dengan memberikan materi video } \\
\text { pembelajaran agar siswa dapat melihat teknik gerakan yang akan } \\
\text { dilakukan, dan untuk tugas praktek guru menugaskan siswa membuat } \\
\text { video gerakan sesuai dengan video pembelajaran yang diberikan } \\
\text { dengan menggunakan metode diskusi kelompok. Tetapi ada juga guru } \\
\text { yang hanya menitik beratkan pada aspek kognitifnya saja dan untuk } \\
\text { materi praktek diganti dengan menganalisis video teknik dasar gerakan. } \\
\text { Dikarenakan guru khawatir jika tidak ada yang mengawasi akan terjadi } \\
\text { hal yang tidak diinginkan (cedera). }\end{array}$ \\
\hline $\begin{array}{l}\text { Kendala dalam } \\
\text { strategi } \\
\text { pembelajaran di } \\
\text { masa pandemi }\end{array}$ & $\begin{array}{l}\text { Strategi pembelajaran daring yang diterapkan oleh Guru PJOK SMK } \\
\text { Negeri di Kota Malang juga memiliki kendala seperti pada penggunaan } \\
\text { metode ceramah yang dimana siswa cenderung tidak memperhatikan } \\
\text { materi yang diberikan. Sedangkan pada metode diskusi kelompok ada } \\
\text { beberapa siswa yang menyerahkan tugas dan tanggung jawabnya ke } \\
\text { temannya. Namun ada pula kendala umum yang sering terjadi pada saat } \\
\text { pembelajaran seperti (1) guru sulit untuk mengukur tingkat } \\
\text { pemahaman siswa pada materi dikarenakan berbagai keterbatasan, (2) } \\
\text { siswa cenderung tidak membaca buku online yang telah diberikan. (3) } \\
\text { untuk tugas praktek ada guru yang takut siswa mengalami cedera } \\
\text { karena tidak ada pengawasan. }\end{array}$ \\
\hline $\begin{array}{l}\text { Management } \\
\text { pengelolaan kelas }\end{array}$ & $\begin{array}{l}\text { Guru membuat beberapa aturan dan komitmen dengan siswa diawal } \\
\text { pembelajaran. sehingga siswa memiliki tanggung jawab serta mematuhi } \\
\text { peraturan yang dibuat dan disepakati bersama. } \\
\text { Ada juga guru yang membagi rata siswa yang dianggap dapat } \\
\text { mengkoordinir teman-temannya di masing-masing kelompok, sehingga } \\
\text { pembelajaran dapat berlangsung secara optimal/baik. }\end{array}$ \\
\hline $\begin{array}{l}\text { Cara guru } \\
\text { menangani siswa }\end{array}$ & $\begin{array}{l}\text { Guru mengingatkan mereka yang belum mengumpulkan tugas dan ada } \\
\text { sebagian guru menghubungi siswa yang bersangkutan langsung }\end{array}$ \\
\hline
\end{tabular}




\begin{tabular}{ll}
\hline Pernyataan & Hasil \\
\hline $\begin{array}{l}\text { yang sulit dalam } \\
\text { pengumpulan tugas }\end{array}$ & $\begin{array}{l}\text { menggunakan aplikasi WhatsApp. adapun guru menyampaikan ke } \\
\text { siswanya bahwa tugas apapun wajib dikumpulkan walaupun dalam } \\
\text { pengumpulannya tidak tepat waktu. }\end{array}$ \\
\hline
\end{tabular}

\subsection{Pembahasan}

Berdasarkan hasil survey yang dilakukan terhadap guru PJOK di SMK Negeri Kota Malang menyatakan bahwa Pembelajaran daring masih diterapkan di SMK Negeri Kota Malang. Hal ini tentunya sesuai dengan surat keputusan pemerintah yaitu rangkaian pembelajaran dilakukan dengan menggunakan pembelajaran secara daring/ jarak jauh dengan tujuan untuk mencegah penyebaran Covid-19 (KEBUDAYAAN \& INDONESIA, 2020). Dalam pembelajaran daring tentunya sangat berkaitan erat dengan akses internet. Menurut (Hasmujaj \& Bushati, 2017) penggunaan internet secara positif dapat membantu proses belajar dalam menggali lebih banyak informasi. Dalam pembelajaran daring guru PJOK menggunakan aplikasi zoom, meet, classroom dan juga WhatsApp. (Salsabila et al., 2020) menyatakan bahwa teknologi pendidikan sangat mendukung sistem pembelajaran jarak jauh dan sebagai penunjang materi pembelajaran sehingga mampu menggapai tujuan yang dicanangkan. Hal tersebut sejalan dengan pendapat (Kuntarto, 2017) menyatakan bahwa pembelajaran daring merupakan suatu desain belajar untuk mengontrol siswa atau kelompok yang luas melalui jaringan internet. Sehingga rangkaian pembelajaran dapat terlaksana meski berada di masa pandemi covid.

Selain penggunaan internet, strategi pembelajaran merupakan faktor pendukung dalam penyampaian materi. Pembelajaran yang digunakan guru PJOK SMK Negeri Kota Malang menggunakan sistem komunikasi sinkronus dan asinkronus. Pada saat pembelajaran sinkronus mayoritas guru menggunakan model pembelajaran langsung dan memakai metode ceramah. Yang dimana guru menyampaikan dan menerangkan materi yang dipelajari melalui platform google meet/zoom/whatsapp secara langsung. Hal tersebut selaras dengan riset (Sukarini, 2020) yang memaparkan penggunaan model pembelajaran langsung mampu memperbesar capaian hasil belajar siswa. Sedangkan pada aktivitas pembelajaran asinkronus guru memberikan softfile agar siswa dapat mempelajari secara berulang-ulang, namun ada juga guru yang menawarkan model strategi kepada siswa untuk mencari materi pembelajaran di internet sesuai dengan tema yang akan dipelajari. Kemudian guru menggunakan metode penugasan kepada siswa untuk merangkum/menganalisis bahan materi yang rampung dikaji. Jika penyampaian tugas oleh guru jelas dan tepat, dapat meningkatkan keberhasilan penggunaan metode penugasan terhadap tujuan yang akan dicapai (Sutarna, 2016).

Pada saat pembelajaran praktek guru menggunakan metode demonstrasi yang dimana guru memberikan materi praktik dengan mendemonstrasikan suatu gerakan melalui video pembelajaran dan ada beberapa guru yang tidak menggunakan video pembelajaran milik sendiri melainkan video pembelajaran yang bersumber dari youtube agar siswa dapat melihat teknik gerakan yang akan dilakukan. Kajian ini relevan dengan luaran penelitian Ramanta \& Widayanti yang menjabarkan bahwa video pembelajaran yang berisikan materi beserta penjelasannya sangat diinginkan oleh siswa (Ramanta \& Widayanti, 2020). Setelah memberikan materi praktik guru memberikan tugas kepada siswa dengan mengadopsi konsep diskusi kolektif yang dimana siswa ditugaskan membuat video gerakan sesuai dengan video pembelajaran yang telah diberikan. Hal tersebut sejalan dengan pendapat Cahyadi bahwa siswa lebih tertarik apabila menggunakan metode diskusi kelompok dari pada metode inkuiri (Cahyadi et al., 2021). Tetapi ada juga guru yang hanya menitik beratkan pada aspek 
kognitifnya saja, sehingga untuk materi praktek diganti dengan menganalisis video teknik dasar gerakan. Dikarenakan guru khawatir jika tidak ada yang mengawasi akan terjadi hal yang tidak diinginkan (cidera). Dari pemaparan strategi yang digunakan oleh guru PJOK tersebut sejalan dengan pernyataan Ansori bahwa guru harus menetapkan unsur dalam strategi pembelajaran seperti: (1) menentukan metode dalam menyampaikan bahan pembelajaran; (2) memilih teknik untuk melaksanakan metode dengan sarana penunjang pembelajaran; (3) merancang penilaian; (4) merancang remedial dan; (5) merancang pengayaan (Asrori, 2013).

Akan tetapi dalam penerapan strategi pembelajaran daring yang digunakan oleh guru PJOK terdapat beberapa kendala yang dialami seperti pada penggunaan metode ceramah yang dimana siswa cenderung tidak memperhatikan materi yang diberikan oleh guru. Karena pembelajaran yang menekankan penyampaian materi satu arah dari guru dianggap membosankan (Sholikhah \& Wahidah, 2021). Sedangkan pada metode diskusi kelompok ada beberapa siswa tidak ikut serta dalam pengerjaan tugas yang dimana dia menyerahkan tugas dan tanggung jawabnya ke temannya. Namun ada pula kendala umum yang sering terjadi pada saat pembelajaran seperti (1) guru sulit untuk mengukur tingkat pemahaman siswa pada materi dikarenakan beragam keterbatasan, (2) siswa cenderung tidak membaca buku online yang telah diberikan. (3) untuk tugas praktek ada guru yang takut siswa mengalami cedera karena tidak ada pengawasan. Terlepas dari kendala dalam strategi pembelajaran siswa juga memiliki kendala teknis yang dihadapi ketika pembelajaran daring/online meliputi tidak memiliki paket internet, tempat tinggal yang susah jaringan, beban tugas yang terlalu banyak dari guru dan juga keaktifan siswa itu sendiri. Hal ini sejalan dengan (Ramanta \& Widayanti, 2020) yang dimana secara kuantitas peserta didik belum semuanya mempunyai sarana fasilitas yang mendorong pemakaian teknologi dalam pembelajaran seperti tidak memiliki gadget; tidak ada kuota internet; dan beberapa guru memberikan materi kurang lengkap. (Asmuni, 2020) juga mengemukakan bahwa aktivitas pengajaran jarak jauh/daring di era pandemi Covid-19 terdapat beberapa kekurangan yang terjadi baik dari pespektif guru, peserta didik, dan orang tua. Tetapi siswa dapat menerima materi yang di sampaikan oleh guru dengan baik.

Adapun cara guru dalam mengelola kelas agar tetap kondusif diantaranya membuat beberapa peraturan dan komitmen dengan siswa diawal pembelajaran, sehingga siswa memiliki tanggung jawab serta wajib mematuhi peraturan yang dibuat dan disepakati bersama. Ada pula guru yang membagi rata siswa yang dianggap dapat mengkoordinir temantemannya di masing-masing kelompok, dengan harapan kualitas aktivitas pengajaran terlaksana lebih bagus, hal ini selaras dengan pernyataan (Kurniawan, 2017) dimana pengaturan kelas, pengaturan waktu dan pengelompokkan siswa dapat menciptakan kelas yang kondusif dan meningkatkan nilai disiplin siswa. Dengan kondisi pembelajaran yang kondusif, siswa lebih termotivasi dalam kegiatan belajar yang nantinya misi dan tujuan yang direncanakan mampu terimplementasi dengan efektif dan efisien (Cahyani et al., 2020). Sedangkan (Alam, 2020) mengemukakan bawah menangani tantangan dengan hati-hati dapat memiliki kesempatan menciptakan suasana positif di bidang Pendidikan.

Dalam menangani siswa yang sulit dalam mengumpulkan tugas, guru memiliki beberapa cara seperti mengingatkan siswa yang belum mengumpulkan tugas melalui grup WhatsApp dan juga menghubungi siswa yang bersangkutan melalui aplikasi WhatsApp. Namun ada sebagian guru menyampaikan ke siswa agar mengumpulkan tugas apapun meski tidak tetap waktu. Sejalan dengan pernyataan (Mcmurtrie, 2020) sangat penting untuk mengingatkan 
siswa serta jangkau siswa lebih awal, bersikap fleksibel tetapi jangan terlalu fleksibel dan berteknologi serendah mungkin.

\section{Simpulan}

Berdsarkan hasil dan pembahasan yang telah dipaparkan, maka peneliti menyimpulkan bahwa pembelajaran di SMK Negeri Kota Malang menggunakan sistem online. Penerapan strategi pembelajaran online yang digunakan menggunakan dua cara yaitu asinkronus dan sinkronus. mayoritas memakai asinkronus dibandingkan sinkronus. Strategi yang digunakan memiliki beberapa kendala pada saat asinkronus yaitu beberapa siswa tidak ikut serta dalam pengerjaan tugas sedangkan kendala pada pembelajaran sinkronus siswa cenderung tidak memperhatikan materi yang dijelaskan. Pada saat pembelajaran asinkronus guru menggunakan metode demonstrasi, metode penugasan dan metode diskusi kelompok sedangkan pada pembelajaran sinkronus guru menggunakan model pembelajaran langsung dengan teknik ceramah. Adapun kendala yang dialami pada pembelajaran asingkronus yaitu beberapa siswa tidak ikut serta dalam pengerjaan tugas sedangkan dalam pembelajaran sinkronus siswa cenderung tidak memperhatikan materi yang diberikan oleh guru. Namun kendala umum yang sering di alami yaitu guru sulit dalam mengetahui pemahaman siswa tentang materi yang diberikan, siswa cenderung tidak membaca buku online yang diberikan, serta guru takut jika siswa mengalami cedera karena tidak adanya pengawasan. Adapun upaya guru agar membuat kelas tetap kondusif dengan membuat peraturan tertentu dan komitmen bersama dengan siswa, sehingga kelas bisa lebih kondusif dalam pembelajaran. Guru juga mengingatkan siswa yang belum mengumpulkan tugas melalui grup WhatsApp atau menghubungi siswa yang bersangkutan secara langsung.

\section{Daftar Rujukan}

Alam, A. (2020). Challenges and possibilities of online education during Covid-19.

Asmuni, A. (2020). Problematika Pembelajaran Daring di Masa Pandemi Covid-19 dan Solusi Pemecahannya. Jurnal Paedagogy, 7(4), 281-288.

Asrori, M. (2013). Pengertian, tujuan dan ruang lingkup strategi pembelajaran. Madrasah: Jurnal Pendidikan Dan Pembelajaran Dasar, 5(2), 26.

Cahyadi, E., Hariyanto, A., \& Kartiko, D. C. (2021). Penerapan Metode Pembelajaran Inkuiri DAN Group Investigation Pada Pembelajaran PJOK Terhadap Partisipasi Dan Berpikir Kritis Siswa SMPN 4 Pamekasan. Jurnal Ilmiah Mandala Education, 7(2).

Cahyani, A., Listiana, I. D., \& Larasati, S. P. D. (2020). Motivasi Belajar Siswa SMA pada Pembelajaran Daring di Masa Pandemi Covid-19. IQ (Ilmu Al-Qur'an): Jurnal Pendidikan Islam, 3(01), 123-140.

Hasmujaj, E., \& Bushati, J. (2017). Internet in education system. Pannoniana: Časopis Za Humanističke Znanosti, $1(2), 71-79$.

Jayul, A., Rekreasi, E. I.-J. P. K., \& 2020, undefined. (n.d.). Model Pembelajaran Daring Sebagai Alternatif Proses Kegiatan Belajar Pendidikan Jasmani di Tengah Pandemi Covid-19. Ojs.Mahadewa.Ac.Id.

Kebudayaan, M., \& Indonesia, R. (2020). Surat Edaran Nomor 4 Tahun 2020 Tentang Pelaksanaan Kebijakan Pendidikan Dalam Masa Darurat Penyebaran Coronavirus Disease (COVID-19).

Ketaren, A. M. A., \& Kanca, I. N. (2021). Efektivitas Proses Pembelajaran Luring Peserta Didik Yang Tinggal Di Asrama Dan Daring Bagi Peserta Didik Di Luar Asrama Terhadap Hasil Belajar PJOK. Jurnal Pendidikan Jasmani, Olahraga Dan Kesehatan Undiksha, 9(1), 29-40.

Kuntarto, E. (2017). Keefektifan model pembelajaran daring dalam perkuliahan bahasa Indonesia di perguruan tinggi. Indonesian Language Education and Literature, 3(1), 99-110.

Kurniawan, R. (2017). Meningkatkan Nilai Karakter Disiplin Melalui Penciptaan Iklim Kelas Kondusif di Kelas IVA SD Negeri 13/I Muara Bulian. Jurnal Edukasi.

McMurtrie, B. (2020). How to Help Struggling Students Succeed Online. The Chronicle of Higher Education. 
Nasution, W. N. (2017). Strategi pembelajaran. Medan: Perdana Publishing.

Organization, W. H. (2020). Coronavirus disease 2019 (COVID-19): situation report, 73.

Ramanta, D., \& Widayanti, F. D. (2020). Pembelajaran daring di sekolah menengah kejuruan putra indonesia malang pada masa pandemi covid-19. Prosiding Seminar Bimbingan Dan Konseling, 61-67.

Salsabila, U. H., Sari, L. I., Lathif, K. H., Lestari, A. P., \& Ayuning, A. (2020). Peran Teknologi Dalam Pembelajaran Di Masa Pandemi Covid-19. Al-Mutharahah: Jurnal Penelitian Dan Kajian Sosial Keagamaan, 17(2), 188198.

Sani, R. A. (2013). Inovasi pembelajaran. Jakarta: Bumi Aksara.

Sholikhah, F. N., \& Wahidah, Z. (2021). Penggunaan Metode Pembelajaran Guru Biologi Di Pasuruan: Analisis Persepsi Siswa. Alveoli: Jurnal Pendidikan Biologi, 2(1), 16-29.

Sugiyono, S. (2017). Metode Penelitian Kuantitatif, Kualitatif, dan Kombinasi (Mixed Methods). Bandung : CV. Alfabeta

Sukarini, N. N. (2020). Meningkatkan Hasil Belajar Pendidikan Jasmani Olah Raga dan Kesehatan (PJOK) Materi Permainan Bola Kecil Sederhana Melalui Penerapan Model Pembelajaran Langsung. Jurnal Ilmiah Pendidikan Profesi Guru, 3(2), 331-338.

Sumbodo, P. P. (2016). Penerapan metode kooperatif tipe teams games tournament (tgt) untuk meningkatkan hasil belajar keterampilan bolavoli pada siswa kelas xi tsm smk murni 1 Surakarta tahun pelajaran 2015/2016.

Sutarna, N. (2016). Penerapan Metode Penugasan Untuk Meningkatkan Kemampuan Memahami Peta Pada Siswa Sekolah Dasar. Jurnal Geografi Gea, 16(1), 34-43.

Ulum, B., \& Or, S. (2020). Strategi Pembelajaran Pendidikan Jasmani, Olahraga Dan Kesehatan Guna Menjaga Imunitas Tubuh Siswa Di Masa Pandemi Covid-19. Bunga Rampai, 17.

Yuangga, K. D., \& Sunarsi, D. (2020). Pengembangan media dan strategi pembelajaran untuk mengatasi permasalahan pembelajaran jarak jauh di pandemi covid-19. JGK (Jurnal Guru Kita), 4(3), 51-58. 